\title{
MUZARA'AH DENGAN SISTEM MURABAHAH SEBAGAI UPAYA MENSTABILKAN HARGA KEDELAI \\ DIMASA PANDEMI COVID-19
}

\author{
Dyah Ochtorina Susanti \\ Fakultas Hukum Universitas Jember \\ Jl. Kalimantan No.76, Krajan Timur, Sumbersari, Jawa Timur 68121 \\ Email: dyahochtorina.fh@unej.ac.id
}

\begin{abstract}
The purpose of this study was to determine the characteristics of the muzara'ah akad with the murabahah system as an alternative in stabilizing soybean prices during the covid-19 pandemic. This normative legal research using statute and conceptual approach, shows that the characteristics of a muzara'ah akad with a murabahah system can be seen from 4 (four) things, namely: First, it consists of 4 (four) people, namely Islamic Banks, Soybean Farmers, Cultivators, and Tempe Producers; Second, the object in the muzara' ah akad with the murabahah system is the form of agricultural capital for the first transaction, and soybeans for the second and third. Third, in this akad, the bank, soybean farmers, and cultivators get a profit, while tempe traders do not get a profit in the form of a margin, but tempe producers benefit, because they can buy soybeans at a lower price. Fourth, soybean farmers who do not have the funds or costs or capital to buy seeds, fertilizers, agricultural equipment, and so on can apply for financing to the bank.
\end{abstract}

Keyword: Muzara'ah, Murabahah System, Soybean Price

\begin{abstract}
Abstrak
Penelitian ini bertujuan untuk menemukan karakteristik akad muzara'ah dengan sistem murabahah sebagai alternatif dalam menstabilkan harga kedelai di tengah pandemic covid19. Penelitian normatif ini menggunakan pendekatan perundang-undangan dan konseptual menghasilkan temuan bahwa karakteristik akad muzara'ah dengan sistem murabahah dapat dilihat dari 4 hal yakni: Pertama, dari segi subyeknya yakni Bank Syariah, Petani Kedelai, Penggarap, dan Produsen Temp; Kedua, obyek di dalam akad muzara'ah dengan sistem murabahah yaitu berupa modal pertanian untuk transaksi pertama dan kedelai untuk transaksi yang kedua dan ketiga. Ketiga, di dalam akad ini, pihak bank, petani kedelai, dan penggarap memperoleh keuntungan, sedangkan pedagang tempe tidak memperoleh keuntungan berupa margin, akan tetapi produsen tempe memperoleh manfaat, sebab dapat membeli kedelai dengan harga murah. Keempat, petani kedelai yang tidak memiliki dana untuk membeli benih, pupuk, alat-alat pertanian, dan lain sebagainya dapat mengajukan permohon pembiayaan kepada bank.
\end{abstract}

Kata Kunci: Muzara'ah, Sistem Murabahah, Harga Kedelai. 


\section{Latar Belakang}

Pandemi Virus Corona Disease 2019 (selanjutnya disebut Covid-19) sampai saat ini masih menjadi permasalahan utama tidak hanya bagi masyarakat Indonesia, akan tetapi juga permasalahan hampir seluruh negara di dunia. Pandemi Covid-19 yang belum bisa diprediksi waktu berakhirnya ini, menimbullkan kekhawatiran dan keresahan bagi masyarakat karena telah memberikan dampak yang luar biasa hampir di segala sektor perekonomian, salah satunya di sektor pertanian, seperti terganggunya pasokan dan kenaikan harga pangan hasil pertanian di wilayah terdampak. ${ }^{1}$ Hal ini tentu menjadi tantangan bagi sektor pertanian, mengingat pangan yang bersumber dari hasil pertanian sangat dibutuhkan masyarakat untuk mempertahankan kehidupannya, terlebih di era pandemi Covid-19, dimana setiap orang harus tetap menjaga kesehatan jiwa dan raga agar tidak tertular virus Covid-19 ini. ${ }^{2}$ Pemerintah, masyarakat maupun stakeholder lainnya harus mampu memberikan solusi yang efektif agar sektor pertanian Indonesia tetap kuat guna mewujudkan ketahanan pangan nasional di masa pandemi Covid-19. ${ }^{3}$ Berkenaan dengan demikian, salah satu hasil pertanian yang dibutuhkan oleh masyarakat sehingga harus dijaga stabilitasnya yakni kedelai.

Kedelai merupakan sumber protein yang menghasilkan minyak dengan mutu yang baik, dimana secara umum kedelai mengandung vitamin B1, B2, niasin, piridoksin dan golongan vitamin B lainnya. Vitamin lain yang terkandung dalam jumlah cukup banyak adalah vitamin $\mathrm{E}$ dan $\mathrm{K}$. Terkait demikian pula, Krisna dalam I Gusti Ayu Ari Agung, menjelaskan bahwa kedelai juga banyak mengandung $\mathrm{Ca}$ dan $\mathrm{P}$, sedangkan Fe terdapat dalam jumlah relatif sedikit, selain itu ada pula mineral lain, Bo, Mg dan $\mathrm{Zn}$ yang terkandung dalam kedelai. ${ }^{4}$ Banyaknya kandungan vitamin, hingga protein di dalam kedelai sebagaimana yang dimaksud menunjukkan bahwa kedelai sudah tentu bermanfaat bagi kesehatan manusia, sehingga tidak heran jika kedelai kemudian diolah oleh masyarakat menjadi salah satu produk makanan yang digemari oleh masyarakat Indonesia yakni tempe. Tempe adalah makanan warisan nenek moyang Indonesia yang memiliki kandungan gizi luar biasa, bahkan lebih unggul daripada daging, bahkan tempe juga mempunyai manfaat untuk mencegah terjadinya penyakitpenyakit kronis seperti penyakit jantung koroner, stroke, hipertensi, kanker, diabetes, obesitas dan lain-lain. ${ }^{5}$ Berkenaan dengan hal tersebut, maka wajar jika tempe yang berbahan dasar kedelai itu menjadi primadona bahkan menjadi salah satu makanan khas dari masyarakat Indonesia.

Berkaitan dengan hal diatas, namun adanya pandemi Covid-19 ini telah berdampak terhadap menipisnya ketersediaan

1 Budi Waryanto, et.al (Ed), "Dampak Covid-19 Terhadap Sektor Pertanian”. Buletin Perencanaan Pembangunan dan Pertanian, Volume 1 No.2, (April 2020), hlm. 1.

2 Ibid.

3 Ibid., hlm. 4.

4 I Gusti Ayu Ari Agung, et. al, "Kedelai Lokal Bali, Bahan Baku Tempe Tinggi Nutrisi, Antioksidan Dan Organoleptik Serta Berkhasiat Obat", AGRIMETA: Jurnal Pertanian Berbasis Keseimbangan Ekosistem, Vol. 6 No. 12, (2016), hlm. 87.

5 Susianto dan Rita, Fakta Ajaib Khasiat Tempe, (Jakarta: Penebar Plus, 2013), hlm. 57. 
kedelai sebagai bahan dasar dari tempe, berminat dalam mengolah hasil pertanian sehingga produksi tempe juga berkurang. berupa kedelai, padahal kebutuhan kedelai Hal ini dikarenakan produksi kedelai dalam setiap tahunnya semakin meningkat, dimana negeri belum mencukupi, sehingga Indonesia harus mengimpor kedelai dari negara-negara lain, seperti Argentina, Amerika Serikat, dan Brazil, sedangkan ketiga negara tersebut pada awal tahun 2021 melakukan aksi mogok kerja logistik dan distribusi yang tentu menghambat proses pengiriman kedelai, termasuk pengiriman ke Indonesia. ${ }^{6}$ Sejalan dengan hal tersebut, Suwandi, Direktur Jenderal Tanaman Pangan, Kementerian Pertanian Republik Indonesia menjelaskan bahwa dampak pandemi Covid-19 menyebabkan pasar global kedelai mengalami goncangan akibat tingginya ketergantungan impor, ${ }^{7}$ termasuk di Indonesia. Berdasarkan Data Pusat Statistik, impor kedelai Indonesia pada tahun 2019 sebesar 1,06 juta ton dan sepanjang semester-I 2020 mencapai 1,27 juta ton. ${ }^{8}$ Terkait hal ini pula, Menteri Pertanian Syahrul Yasin Limpo juga menambahkan bahwa menipisnya pasokan kedelai di Indonesia disebabkan oleh sebagian besar para petani yang tidak kebutuhan nasional terhadap kedelai rata-rata sebesar 2,5 juta ton per tahun. ${ }^{9}$

Berdasarkan penjelasan di atas, maka dapat dilihat bahwa ketersediaan jumlah atau produksi kedelai secara nasional dengan kebutuhan kedelai masyarakat Indonesia belum terpenuhi, sehingga pemerintah mengambil langkah untuk melakukan impor kedelai. Terkait demikian, namun dengan adanya pandemi Covid-19 tentu memberikan efek yang luar biasa terhadap sektor pertanian kedelai yakni naiknya harga kedelai impor, ${ }^{10}$ dan hal ini tentu merugikan petani kedelai serta pedagang tempe karena dengan mahalnya harga kedelai, maka harga tempe pun juga ikut naik. Hal ini dikarenakan petani kedelai tidak memiliki modal untuk meningkatkan produksinya, dan pedagang tempe juga tidak memilik cukup modal untuk membeli kedelai, alhasil para pedagang tempe pun melakukan pengurangan terhadap jumlah produksi tempe yang dijalaninya. ${ }^{11}$

6 Hal ini dapat dilihat sebagaimana data Badan Pusat Statistik yang mencatat produksi kedelai mengalami penurunan dimana pada tahun 2016 tercatat Indoensia memproduksi kedelai sebanyak 859.653 ton per tahun, dan pada tahun 2017 produksi kedelai mengalami penurunan yakni 538.728, kemudian pada tahun 2019 hanya mencapai 420.000 ton. Lihat https://www.bps.go.id/, lihat pula https://money.kompas.com/ $\mathrm{read} / 2020 / 08 / 23 / 071100726 /$ ironi-indonesia-negeri-tempe-kedelainya-mayoritas-impor?page=all., $\quad$ diakses pada tanggal 1 Maret 2021.

7 https://www.cnbcindonesia.com/news/20210104144905-4-213360/tahu-tempe-langka-terus-yang-salahpetani-kedelai-gitu, diakses pada tanggal 1 Maret 2021.

8 Lihat https://www.bps.go.id/, diakses pada tanggal 1 Maret 2021.

9 Lihat https://finance.detik.com/berita-ekonomi-bisnis/d-5324643/harga-kedelai-rp-8500kg-ditahan-3-bulan. Lihat pula https://money.kompas.com/read/2020/08/23/071100726/ironi-indonesia-negeri-tempe-kedelainyamayoritas-impor?page=all, diakses pada tanggal 1 Maret 2021.

10 Sekitar bulan Januari-Februari 2021, harga kedelai mengalami kenaikan yang cukup signifikan yakni yang awalnya seharga Rp 6000 - Rp $6.500 / \mathrm{kg}$, naik menjad Rp 10.000/kg. Lihat https://www.antaranews.com/ berita/2002109/naik-lagi-harga-kedelai-impor-di-kudus-rp9800-per-kilogram, diakses pada tanggal 1 Maret 2021.

11 Hal ini sebagaimana salah satu pedagang tempe bernama Siti Juwariyah yang mengurangi jumlah produksi tempenya. Adapula Abdurrahman yang menaikkan harga tempenya yang semula tempe berukuran sedang dijual dengan harga $\mathrm{Rp} 1.000$ kemudian dinaikkan menjadi $\mathrm{Rp} 1.500$ per potongnya. Lihat https://bisnis. tempo.co/read/312935/pengusaha-tahu-tempe-di-jember-juga-mulai-kelimpungan/full\&view=ok, diakses pada tanggal 1 Maret 2021. 
Berdasarkan penjelasan sebagaimana yang diuraikan di atas, tentu diperlukan suatu upaya dalam mendorong produksi kedelai dalam negeri agar ketersediaan kedelai terpenuhi dan Indonesia tidak bergantung pada impor kedelai, serta menstabilkan harga kedelai dalam negeri, sehingga pedagang tempe (produsen tempe) dapat meningkatkan produksi tempe, mengingat tempe merupakan salah satu jenis makanan yang digemari bahkan menjadi ciri khas dari masyarakat Indonesia. Mengatasi hal tersebut, maka penulis memberikan pemikiran agar produksi kedelai dalam negeri dapat meningkat yakni melalui penggunaan akad muzara'ah dengan sistem murabahah.

\section{Akad Muzara'ah dengan sistem} murabahah merupakan penggabungan dua akad yakni akad muzara'ah dan akad murabahah. Akad muzara'ah sendiri yaitu suatu kerjasama antara pemilik lahan (pemilik modal) dengan petani penggarap, dimana bibit yang ditanam berasal dari pemilik lahan. ${ }^{12}$ Lanjut dengan definisi akad murabahah adalah akad jual beli dimana harga dan keuntungan telah disepakati antar para pihak, sedangkan pembayaran dapat dilakukan secara mengansur (cicil) atau tunai. ${ }^{13}$ Penggabungan kedua akad ini merupakan temuan baru di dalam ekonomi Islam, yang memerlukan analisa dan pemahaman terhadap unsur-unsur yang ada di dalam akad untuk menemukan ciri khas dari akad muzara'ah dengan sistem akad murabahah sehingga dapat digunakan sebagai solusi dalam menstabilkan harga kedelai dalam negeri sehingga dapat menigkatkan produksi kedelai yang menjadi bahan dasar tempe.

Berdasarkan latar belakang di atas, maka terdapat isu atau permasalahan yang menarik untuk dibahas yaitu apa karakteristik akad muzara'ah dengan sistem murabahah, sehingga dapat digunakan sebagai upaya menstabilkan harga kedelai di masa pandemic covid-19? Terkait demikian, untuk memecahkan permasalahan tersebut, penulis menggunakan metode penelitian hukum normatif (normatif legal research), ${ }^{14}$ dengan 2 (dua) pendekatan yakni pertama, pendekatan perundang-undangan digunakan untuk menelaah peraturan perundang-undangan yang berkaitan dengan syarat-syarat atau ketentuan akad muzara' ah, sistem murabahah, serta mekanisme pelaksanaannya, dan kedua, pendekatan konseptual digunakan untuk mancari, menemukan, pengertian, syarat, dan mekanisme akad muzara'ah maupun sistem murabahah menurut para ahli, guna menemukan karakteristik akad muzara'ah dengan sistem murabahah sebagai upaya menstabilkan harga kedelai di masa pandemic Covid-19.

12 Teungku Muhammad Hasbi As-Shiddieqy, Hukum-Hukum Fikih Islam, (Semarang: Pustaka Rizki Putra, 1997), hlm. 125.

13 Bambang Hermanto, Lembaga Keuangan Syari’ah, (Pekanbaru : Suska Press, 2008), hlm.63.

14 Dyah Ochtorina Susanti dan A'an Efendi, Penelitian Hukum (Legal Research), (Jakarta: Sinar Grafika, 2014), hlm. 11. Penelitian hukum normatif (normatif legal research) yakni penelitian yang bersifat sistematis, artinya mekanisme yang dilakukan yaitu dengan mencari dan mengumpulkan aturan hukum yang mengatur bidang hukum tertentu, menganalisis hubungan antara aturan hukum yang satu dengan yang lain, menjelaskan bagianbagian yang sulit untuk dipahami dari suatu aturan hukum tertentu, bahkan dimungkinkan pula mencakup prediksi perkembangan suatu aturan hukum tertentu pada masa mendatang. 


\section{Pembahasan}

A. Akad Muzara'ah sebagai Akad Kerjasama yang Modalnya Berasal dari Pemilik Lahan Pertanian

Pada tataran etimologi, muzara'ah memiliki dua arti yaitu al-budzar artinya modal $^{15}$ dan tharh al-zur'ah artinya melemparkan tanaman. ${ }^{16}$ Pada tataran terminologi, muzara'ah yaitu akad untuk bercocok tanam dengan sebagian yang keluar dari bumi. ${ }^{17}$ Hukum positif Indonesia juga mengatur mengenai muzara'ah tepatnya pada Pasal 20 angka 5 Peraturan Mahkamah Agung Republik Indonesia Nomor 2 Tahun 2008 tentang Kompilasi Hukum Ekonomi Syariah (selanjutnya disebut KHES), yakni:

"Muzara'ah adalah kerjasama antara pemilik lahan dengan penggarap untuk memanfaatkan lahan."

Definisi lainnya juga dikemukakan oleh para ahli, diantaranya Syaikh Ibrahim Al-bajuri dalam Hendi Suhendi menerangkan bahwa muzara'ah adalah kerjasama antara pekerja mengelola tanah dengan sebagian apa yang dihasilkan darinya dan pemilik tanah sebagai penyedia modal. ${ }^{18}$ Berbeda konteks dari kedua pendapat tersebut, Mardani dalam Benny menerangkan bahwa muzara'ah adalah akad transaksi kerjasama pengolahan pertanian antara pemilik lahan dan penggarap, dimana pemilik lahan memberikan lahan dan benih kepada penggarap untuk menanami dan memelihara dengan imbalan pembagian (persentase) dari hasil panen. ${ }^{19}$ Senada dengan pendapat Mardani, Muhammad Syafi'i Antonio menjelaskan bahwa muzara'ah adalah kerja sama pengolahan pertanian antara pemilik lahan dan penggarap, dimana pemilik lahan memberikan lahan pertanian kepada si penggarap untuk ditanami dan dipelihara dengan imbalan bagian tertentu dari hasil panen. $^{20}$

Adapula Fachruddin dalam Rio Makkulau Wahyu, mengatakan hal yang sama bahwa muzara'ah merupakan istilah yang digunakan dalam perjanjian antara petani penggarap dan pemilik tanah, dengan memberikan tanah itu kepada petani untuk diusahakan, dan hasilnya dibagi antara keduanya. ${ }^{21}$ Lebih lengkap

15 Sehubungan dengan modal dalam akad muzara'ah, sebenarnya terdapat istilah lain yang sama dengan muzara'ah namun berbeda dari segi modalnya, yakni mukhabarah. Terkait demikian, bahkan menurut Hanafiyah, mukhabarah dan muzara'ah hampir tidak bisa dibedakan. Persamaan dari keduanya yaitu pemilik tanah menyerahkan tanahnya kepada orang lain untuk dikelola. Berkenaan dengan perbedaannya, terletak pada modal, dimana untuk mukhabarah modal berasal dari pengelola, sedangkan muzara'ah modal berasal dari pemilik tanah. Lihat Jefri Putri Nugraha, "Sistem Muzara'ah Sebagai Alternatif Pembiayaan Pertanian di Indonesia", Jurnal Iqtishodia Vol. 1, No. 2, (September 2016), hlm. 87.

16 Nazaruddin, "Mukhabarah Sebagai Problem Solver Umat", Al-Mabhats: Jurnal Penelitian Sosial Agama Vol. 4, No. 2, (2019), hlm. 103.

17 Muhammad Ngasifudin, “Aplikasi Muzara'ah Dalam Perbankan Syariah”, Jurnal Ekonomi Syariah Indonesia, Vol. VI No. 1, (Juni 2016), hlm. 39.

18 Hendi Suhendi, Fiqih Mu'amalah, (Jakarta: Raja Grafindo Persada, 2013), hlm. 154.

19 Beny Septyliyan Primada, "Tinjauan Mekanisme Kontrak Pengelolaan Lahan Pertanian Berbasis Adat Istiadat Dalam Kajian Fiqh Muamalah (Desa Temu, Kecamatan Kanor, Kabupaten Bojonegoro)”, JESTT Vol. 2, No. 11 (November 2015), hlm. 959.

20 Muhammad Syafi’i Antonio, Bank Syariah Teori dan Praktek, (Jakarta: Gema Insani, 2001), hlm. 103.

21 A. Rio Makkulau Wahyu, "Sistem Penggarapan Lahan Pertanian Masyarakat: Perspektif Ekonomi Islam", AlAzhar Journal of Islamic Economics Vol. 1 No. 1, (Januari 2019), hlm. 5. 
lagi, Muslich dalam Jefri Putri Nugraha juga mengemukakan pendapat yang sama bahwa muzara' $a$ h adalah suatu akad kerja sama antara dua orang yaitu pemilik tanah dan penggarap, dimana pemilik tanah menyerahkan tanahnya kepada penggarap untuk diolah sebagai tanah pertanian dan hasilnya dibagi diantara kedua belah pihak dengan perimbangan setengah setengah, atau sepertiga, dua pertiga, atau lebih kecil atau, atau lebih besar dari nisbah tersebut sesuai dengan hasil kesepakatan para pihak. ${ }^{22}$ Berdasarkan beberapa definisi muzara'ah diatas, maka dapat dipahami bahwa pada intinya muzara'ah merupakan akad kerjama antara pemilik lahan dengan penggarap, dimana modal berupa benih atau bibit, pupuk, alat pertanian, dan bahan-bahan lainnya disediakan oleh pemilik lahan. ${ }^{23} \mathrm{Hal} \mathrm{ini}$ sebagaimana kerjasama antara petani kedelai selaku pemilik lahan dengan penggarap, dimana lahan, termasuk modal yang meliputi benih atau bibit, pupuk, alat pertanian, dan bahan-bahan lainnya disediakan oleh petani kedelai, sedangkan penggarap hanya menyediakan keahlian, tenaga, dan waktu saja, dimana hasil panennya dibagi sesuai kesepakatan para pihak. Terkait penjelasan di atas, untuk lebih jelasnya, dapat dilihat pada Gambar 1:

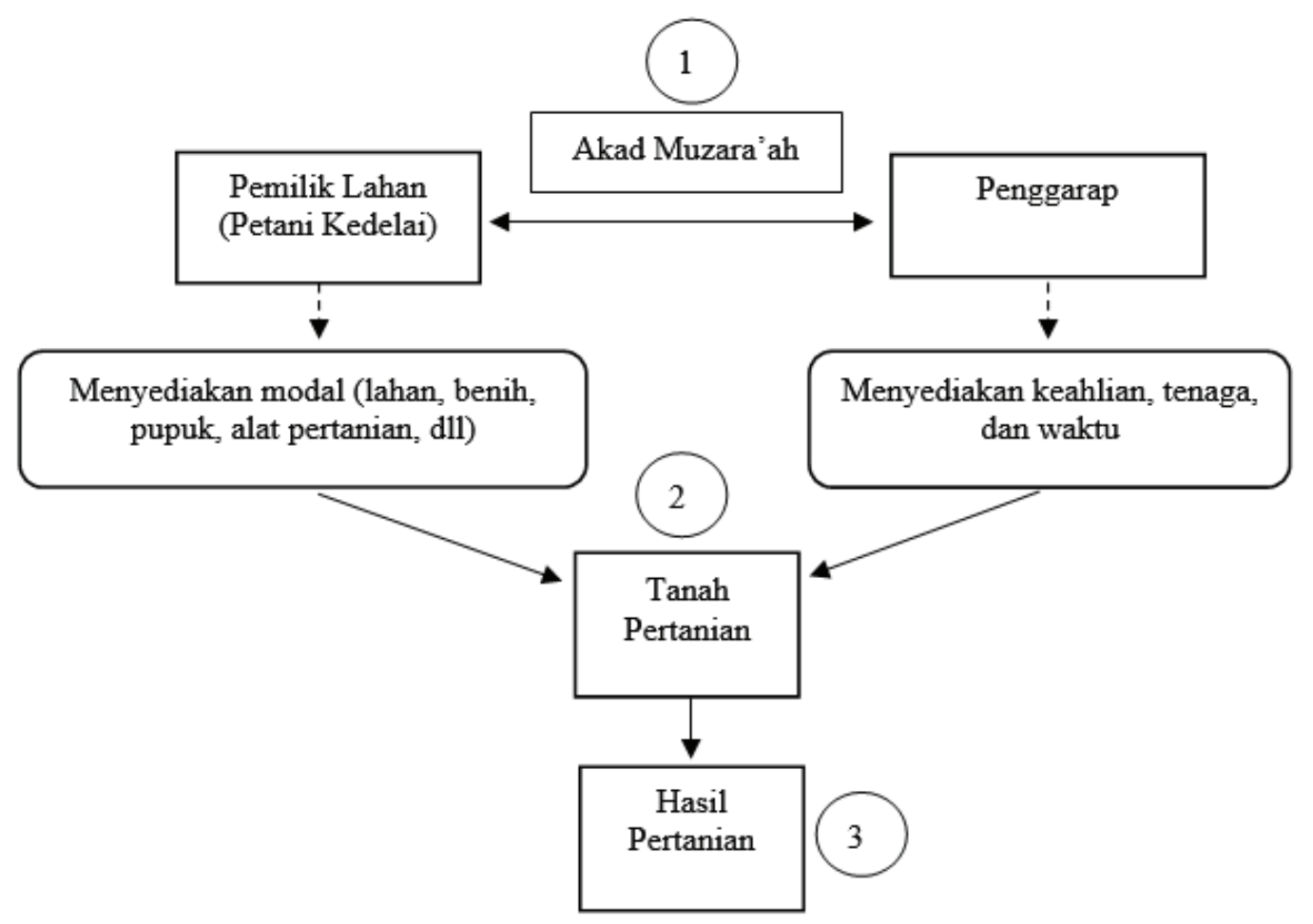

Gambar 1.

Skema Akad Muzara'ah

Sumber: Catatan Pribadi Penulis, diolah, 2021

22 Jefri Putri Nugraha. Op. Cit., hlm. 87.

23 Ana Liana Wahyuningrum dan Darwanto, "Penerapan Bagi Hasil Maro PerspektifAkad Mukhabarah, Tawazun: Journal of Sharia Economic Law, Vol. 3 No. 1, (2020), hlm. 49. 
Berdasarkan skema di atas, maka dapat dilihat alur dari pelaksanaan akad muzara'ah yaitu:pertama, pemilik lahan atau tanah(dalam hal ini petani kedelai) selaku penyedia modal berupa lahan benih, pupuk, alat pertanian, dan lain-lain) melakukan akad muzara'ah dengan penggarap selalu pengelola lahan yang menyediakan keahlian, tenaga, dan waktu. Kedua, modal dari pemilik lahan selanjutnya diserahkan kepada penggarap yang juga siap menggunakan keahlian, tenaga, dan waktunya untuk mengelola lahan pertanian tesebut. Ketiga, hasil pertanian selanjutnya dibagi antara pihak pemilik lahan dan penggarap sesuai kesepakatan yang telah diperjanjikan di awal akad. ${ }^{24}$

Berkenaan dengan besaran pembagian hasil kerjasama menggunakan akad muzara'ah ini, diatur di dalam salah satu Hadits yang diriwayatkan oleh Bukhari dari Jabir bahwa bangsa arab senantiasa mengolah tanahnya secara muzara'ah dengan rasio bagi hasil 1/3:2/3, 1/4:3/4, 1/2:1/2, maka Rasulullah SAW pun bersabda:

"Hendaklah menanami atau menyerahkannya untuk digarap. Barang siapa tidak melakukan salah satu dari keduanya, tahanlah tanahnya." 25

Sehubungan dengan kebolehan penggunaan akad ini, Islam bahkan telah menganjurkan manusia untuk mengelola dan memakan apapun yang disediakan di muka bumi, termasuk mengelola pertanian berupa kedelai untuk dimanfaatkan menjadi tempe. Hal ini sebagaimana Hadits yang diriwayatkan oleh Bukhari dan Muslim dari Ibn Abbas ra:26

"Sesungguhnya Nabi Muhammad SAW menyatakan, tidak mengharamkan bermuzara'ah bahkan beliau menyuruhnya, supaya yang sebagian menyayangi sebagian yang lain,dengan katanya, barang siapa yang memiliki tanah, maka hendaklah ditanaminya atau memberikan faedahnya kepada saudaranya, jika ia tidak mau maka boleh ditahan saja tanah itu." (HR. Bukhari dan Muslim)

\section{B. AkadMurabahah sebagai Akad Jual Beli dengan Margin Keuntungan}

Pada tataran etimologi, murabahah berasal dari kata $A r-R i b h u$, yang berarti pelebihan, sedangkan menurut ahli fiqih murabahah adalah jual beli barang dagangan dengan menyebutkan harga pembelian dan labanya, ${ }^{27}$ atau dapat diartikan lain yakni keuntungan. ${ }^{28}$ Pada tataran terminologi, murabahah adalah penjualan barang seharga barang ditambah keuntungan yang disepakati.29 Dilihat dari sudut pandang fiqih Islam, murabahah

24 Terkait pembagian keuntungan ini juga disebut di dalam Pasal 258 Peraturan Mahkamah Agung Nomor 2 Tahun 2008 tentang Kompilasi Hukum Ekonomi Syariah, yang isinya: "Penggarap wajib memberikan keuntungan kepada pemilik lahan bila pengelolaan yang dilakukannya menghasilkan keuntungan."

25 Rivandi, Dhody Ananta dan Sholihah, Cucu, Akad Pembiayaan Murabahah di Bank Syariah dalam Bentuk Akta Otentik Implementasi Rukun, Syarat, dan Prinsip Syariah, (Malang: Cita Intrans Selaras, 2019), hlm. 59.

26 Muhammad Ngasifudin, Op. Cit., hlm. 40.

27 Tri Setiady, "Pembiayaan Murabahah dalam Perspektif Fiqh Isam, Hukum Positif dan Hukum Syariah", Fiat Justisia Jurnal Ilm Hukum, Vol. 8 No. 3, (Juli-September 2014), hlm. 521.

28 Burhanuddin, Hukum Kontrak Syariah, (Yogyakarta: BPFE, 2009), hlm. 82.

29 Bagya Agung Prabowo, "Konsep Akad Murabahah Pada Perbankan Syariah (Analisa Kritis Terhadap Aplikasi Konsep Akad Murabahah Di Indonesia dan Malaysia)”, Jurnal Hukum Vol. 16 No. 1, (Januari 2009), hlm. 108. 
diartikan sebagai salah satu bentuk jual beli ketika penjual menyatakan biaya perolehan barang, meliputi harga barang dan biaya-biaya lain yang dikeluarkan untuk memperoleh barang tersebut, dan tingkat keuntungan (margin) yang diinginkan.30

Defini lain murabahah juga diatur di dalam beberapa peraturan perundang-undangan, seperti Undang-Undang Nomor 21 Tahun 2008 tentang Perbankan Syariah (selanjutnya disebut UU Perbankan Syariah), yang menyebutkan bahwa murabahah adalah akad pembiayaan suatu barang dengan menegaskan harga belinya kepada pembeli dan pembeli membayarnya dengan harga yang lebih sebagai keuntungan yang disepakati.31 Adapula KHES, yang menjelaskan bahwa murabahah adalah pembiayaan saling menguntungkan yang dilakukan oleh shahib al-mal (pemilik dana) dengan pihak yang membutuhkan dana atau uang melalui transaksi jual beli dengan ketetuan bahwa harga pengadaan barang dan harga jual terdapat nilai lebih yang merupakan keuntungan atau laba bagi shahib al-mal (pemilik dana), dimana pengembaliannya dilakukan secara tunai ataupun angsuran.32 Pada lingkup Perbankan Syariah, murabahah merupakan bentuk pembiayaan dimana bank sebagai pemilik dana membelikan barang sesuai dengan spesifikasi yang diinginkan oleh nasabah, kemudian barang tersebut dijual kepada nasabah dengan harga jual plus margin (keuntungan).33 Terkait demikian, untuk lebih jelasnya, dapat dilihat pada Gambar 2.

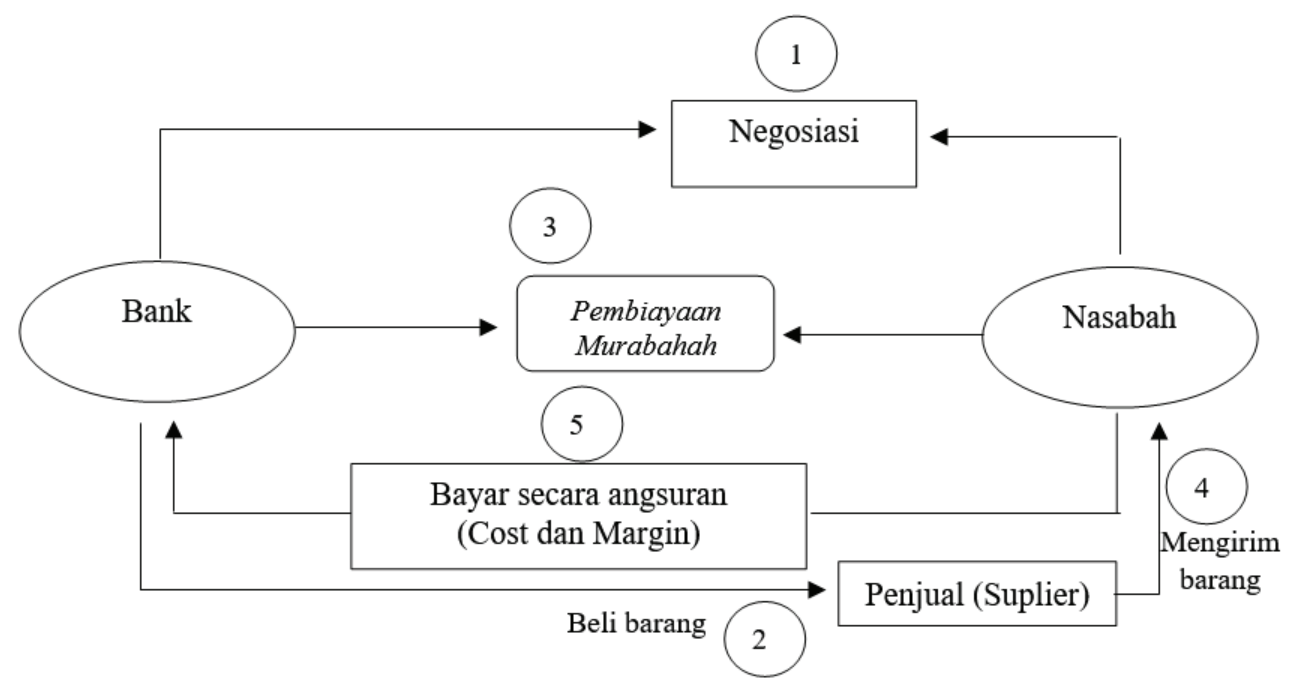

Gambar 2. Skema Pembiayaan Murabahah di Perbankan Syariah ${ }^{34}$

Sumber: Ascarya, diolah, 2021

30 Ascarya, Akad dan Produk Bank Syariah (Jakarta: RajaGrafindo Persada, 2008), hlm. 81.

31 Lihat Penjelasan Pasal 19 ayat (1) huruf d Undang-Undang No. 21 Tahun 2008 tentang Perbankan Syariah.

32 Pasal 20 angka 6 Peraturan Mahkamah Agung Nomor 2 Tahun 2008 tentang Kompilasi Hukum Ekonomi Syariah, yang isinya sebagai berikut: "Murabahah adalah pembiayaan saling menguntungkan yang dilakukan oleh shahib al-mal dengan pihak yang membutuhkan melalui transaksi jual beli dengan penjelasan bahwa harga pengadaan barang dan harga jual terdapat nilai lebih yang merupakan keuntungan atau laba bagi shahib al-mal dan pengembaliannya dilakukan secara tunai atau angsur." Lihat Tim Penyusun Direktorat Badan Peradilan Agama, Kompilasi Hukum Ekonomi Syariah, (Jakarta: Direktorat Badan Peradilan Agama, Mahkamah Agung RI, 2011), hlm. 10.

33 Ascarya, Op. Cit., hlm. 83.

34 Ibid., hlm. 82. 
Skema pembiayaan murabahah di atas memperlihatkan beberapa tahapan yang dilalui diantaranya: pertama, nasabah mengajukan permohonan pembiayaan murabahah kepada bank syariah. Bank dan nasabah selanjutnya melakukan negosiasi mulai dari spesifikasi barang yang diinginkan, harga, margin (keuntungan), hingga metode pembayaran. Kedua, Jika bank menyetujui permohonan nasabah, bank akan membeli barang yang dibutuhkan nasabah ke supplier. Ketiga, Bank Syariah dan nasabah kemudian membuat perjanjian atau akad murabahah yakni bank menjual barang kepada nasabah dengan harga jual ditambah margin (keuntungan) sesuai dengan kesepakatan bersama. Kesepakatan harga ini tidak boleh berubah hingga berakhirnya akad pembiayaan (sesuai jangka waktu yang disepakati). Keempat, bank selanjutnya meminta supplier untuk mengirimkan barang ke alamat nasabah, atau bisa juga barang langsung diserahkan oleh bank kepada nasabah. Kelima, nasabah kemudian melakukan pembayaran barang yang dibelinya secara angsuran sesuai jangka waktu yang telah disepakati oleh kedua belah pihak.

\section{Karakteristik Akad Muzara'ah dan Sistem Murabahah sebagai Solusi dalam Meningkatkan Produksi Kedelai di Indonesia}

Gagasan penulis untuk menggabungkan akad muzara'ah dengan sistem murabahah merupakan suatu upaya untuk meningkatkan kesejahteraan petani kedelai dan pedagang atau produsen tempe. Hal ini dikarenakan dengan adanya penggabungan dua akad tersebut, maka petani kedelai tidak akan mengalami kesulitan modal sehingga dapat meningkatkan kualitas dari kedelainya agar tidak kalah dengan kedelai impor, selain itu produsen kedelai juga bisa memperoleh harga yang terjangkau namun dengan kualitas bagus, mengingat pada akad muzara'ah dengan sistem murabahah ini, terdapat keterlibatan pihak yang menjadi penyedia modal berupa bibit yang berkualitas, pupuk, alat pertanian, dan bahan-bahan lain yang diperlukan untuk meningkat kuantitas dan kualitas dari kedelai yang dihasilkan oleh petani lokal, dimana pihak sebagaimana yang dimaksud yakni bank syariah. Terkait demikian pula, untuk lebih memahami akad muzara'ah dengan sistem murabahah, dapat dilihat pada Gambar 3.

Skema di atas memperlihatkan alur pelaksanaan akad muzara'ah dengan sistem murabahah yang terdiri dari 6 (enam) tahapan, yaitu:

1. Pemilik lahan mengajukan permohonan pembiayaan murabahah untuk pengadaan benih kedelai, pupuk, alatalat pertanian, dan bahan-bahan lain kepada Bank Syariah. Bank dan pemilik lahan (nasabah) selanjutnya melakukan negosiasi terkait deskripsi benih, pupuk, alat pertanian, dan bahan-bahan lainnya yang dibutuhkan oleh petani kedelai; harga barang, margin (keuntungan), metode pembayaran, dan lain-lain. Jika 


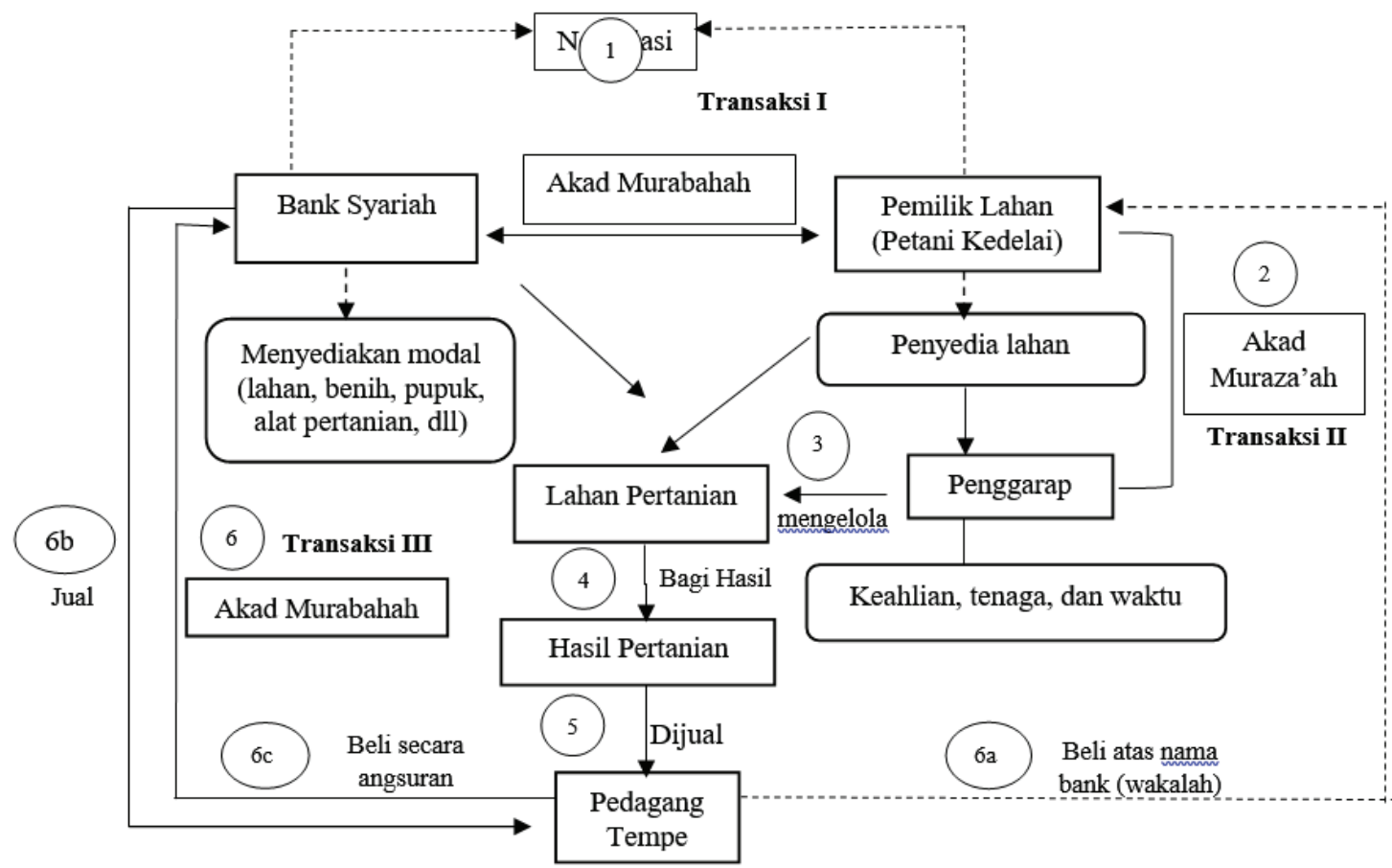

Gambar 3. Skema Akad Muzara'ah dengan Sistem Murabahah

Sumber: Catatan Pribadi Penulis, diolah, 2021

bank menyetujui permohonan nasabah, bank selanjutnya membeli barang sesuai spesifikasi dari nasabah.

2. Bank dan nasabah selanjutnya menuangkan hasil kesepakatan ke dalam perjanjian tertulis menggunakan akad murabahah. Pada tahap inilah terjadi transaksi dimana bank menyerahkan barang (benih kedelai, pupuk, dll) kepada petani kedelai, selanjutnya petani kedelai (nasabah) menyerahkan uang pembayaran dengan harga sesuai kesepakatan para pihak, baik secara tunai maupun angsuran.

3. Petani kedelai selanjutnya mengadakan kerjasaa menggunakan akad muzara'ah dengan penggarap. Pada tahap ini, petani kedelai dan penggarap melakukan negosiasi mulai dari bagi hasil panen, risiko, dan hal-hal lainnya. Jika telah mencapai mufakat, maka petani kedelai menyerahkan lahan beserta benih, pupuk, dan bahan-bahan lainnya kepada penggarap untuk dikelola.

4. Setelahkedelai panen, maka petanikedelai dan penggarap melakukan pembagian hasil sesuai dengan kesepakatan di awal akad. Pembagian hasil untuk penggarap diberikan dalam bentuk uang, sedangkan hasil panen berupa kedelai diserahkan seluruhnya kepada petani kedelai.

5. Hasil panen kemudian dijual ke pedagang tempe (produsen tempe).

6. Apabila pedagang tempe (produsen tempe) tidak memiliki biaya untuk membeli kedelai, maka dapat mengajukan pembiayaan murabahah kepada bank syariah, dengan tahapan sebagai berikut: 
a. Jika bank menyetujui permohonan, maka pedagang tempe membeli kedelai atas nama bank syariah (wakalah).

b. Bank menjual barang (kedelai) kepada pedagang tempe dengan harga jual plus margin (keuntungan) sesuai dengan kesepakatan para pihak.

c. Petani kedelai (nasabah) membeli kedelai secara mengangsur sesuai jangka waktu yang telah ditentukan.

Berdasarkan tahapan-tahapan di atas, maka dapat ditemukan unsurunsur yang dapat dijadikan tolak ukur untuk menemukan karakteristik akad muzara'ah dengan sistem murabahah, yakni:

1. Subyek di dalam akad muzara'ah dengan sistem murabahah

Subyek akad dalam hal ini merupakan para pihak yang melakukan akad atau perjanjian, dimana pihak pihak yang melakukan akad merupakan faktor utama pembentukan suatu perjanjian. ${ }^{35}$ Pihak - pihak sebagaimana yang dimaksud bisa orang perseorangan, kelompok orang, persekutuan, atau badan usaha. ${ }^{36}$ Merujuk pada skema di atas, maka subyek di dalam akad muzara'ah dengan sistem murabahah ini terdiri dari 4 (empat) pihak yakni Bank Syariah, Petani Kedelai, Penggarap, dan Pedagang Tempe. Keempat pihak tersebut terbagi ke dalam 3 (tiga) transaksi yang terkandung di dalam akad ini. Pada transaksi pertama yang menggunakan akad murabahah, para pihaknya terdiri dari Bank Syariah sebagai penjual, dan petani kedelai sebagai pembeli. Lanjut pada transaksi kedua yang menggunakan akad muzara'ah, dimana para pihaknya terdiri dari petani kedelai sebagai pemilik lahan dan penyedia modal (benih, pupuk, dll), dan penggarap sebagai pengelola lahan yang menyediakan kemampuan, tenaga, dan waktu. Pada transaksi ketiga yang menggunakan -pembiayaan murabahah, para pihaknya terdiri dari Bank Syariah sebagai pemberi modal, petani kedelai,sebagai penjual, dan pedagang tempe (produsen tempe) .

Pada pelaksanaannya, untuk dapat melaksanakan suatu perjanjian atau akad muzara'ah dengan sistem murabahah, maka para pihak harus berakal, artinya para pihak dapat menentukan baik dan buruk, serta tidak gila. Para pihak juga harus cakap dalam melakukan perbuatan hukum, artinya para pihak yang melaksanakan akad harus dewasa, ${ }^{37}$

35 Dyah Ochtorina Susanti, Pelaksanaan Perjanjian Pembiayaan Murabahah Dengan Sistem Bai’u Salam Ditinjau Dari Sudut Pandang Hukum Islam ( Studi pada PT. BPRS Daya Artha Mentari Bangil - Pasuruan ), Tesis. (Malang: Program Pascasarjana Fakultas Hukum Universitas Brawijaya, 2006), hlm. 57.

36 Lihat Pasal 23 ayat (1) Peraturan Mahkamah Agung Republik Indonesia Nomor 2 Tahun 2008 tentang Kompilasi Hukum Ekonomi Syariah.

37 Sehubungan dengan yang dimaksud dewasa, terdapat beberapa ketentuan yang berbeda-beda adalam meberikan kriteria dewasa, diantaranya:

a. Menurut Islam, yang disebut baligh atau dewasa yaitu apabila berumur 15 tahun, atau telah bermimpi basah (bagi anak laki-laki) dan haid (bagi anak perempuan);

b. Menurut Pasal 330 Burgerlijk Wetboek, usia dewasa yakni 21 tahun dan telah kawin.

c. Menurut Pasal 7 ayat (1) Undang-Undang Nomor 16 Tahun 2019 tentang Perubahan Atas Undang-Undang Nomor 1 Tahun 1974 tentang Perkawinan, disebut dewasa ketika seseorang telah berusia 19 tahun baik laki-aki maupun perempuan. 
atau tidak berada di bawah pengampuan/ perwalian. ${ }^{38}$ Terlebih akad ini bukanlah akad jual beli barang biasa, artinya barang yang dibeli merupakan benih kedelai, pupuk, ataupun hal-hal lainnya yang tentu harus dilakukan orang dewasa yang berakal sehat guna menentukan spesifikasi benih, pupuk, atau bahan lainnya agar dapat menghasilkan kedelai yang berkualitas.

2. Obyek di dalam Akad Muzara'ah dengan Sistem Murabahah.

Objek akad merupakan barang/ benda yang dibeli, dimana barang sebagaimana yang dimaksud harus memenuhi hal-hal yakni: pertama, Suci dan halal, bukan barang haram atau najis, hal ini sebagaimana yang diatur di dalam bagian Pertama angka 2 Fatwa Dewan Syari'ah Nasional Nomor 04/DSN-MUI/ IV/2000 tentang Murabahah, yakni:

"Barang yang diperjualbelikan tidak diharamkan oleh syari'ah Islam ".

Adapula hadits Nabi Muhammad SAW yang terjemahannya sebagai berikut: ${ }^{39}$

Dari Jabir bin Abdillah ra. Mendengar Rasulullah saw, bersabda pada waktu pembukaan kota Mekkah:" Sesungguhnya Allah telah mengharamkan penjualan khamer (arak) dan bangkai babi dan berhala." Kemudian Nabi ditanya, "Ya Rasulullah? bagaimana pendapatmu tentang lemaknya bangkai, karena itu digunakan untuk menempel perahu dan meminyaki kulit dan digunakan untuk lampu." Maka sabda Nabi SAW: "Tidak boleh, itu haram." Kemudian Nabi SAW bersabda: "Allah telah membinasakan orang Yahudi, sesungguhnya Allah Ta'ala ketikamengharamkan kepada orang Yahudi lemak, maka mereka olah kemudian mereka jual dan mereka makan harga penjualan itu." (H.R. Bukhari \& Muslim).

Kedua, barang yang dibeli harus bermanfaat, artinya barang yang dijual atau dibeli harus ada manfaatnya, dan benar-benar dibutuhkan. Hal ini sebagaimana firman Allah SWT di dalam Q.S. Al-Isra Ayat 27, yang terjemahannya sebagai berikut: ${ }^{40}$

"Sesungguhnya orang-orang yang pemboros itu adalah saudara setan dan setan itu sangat ingkar kepada Tuhannya."

Ketiga, barang itu ada sehingga dapat diserahkan kepada pembeli, jadi bukan menjual barang yang tidak pasti dan tidak jelas (gharar); Keempat, barang yang menjadi obyek jual beli merupakan milik penjual, kepunyaan yang diwakilinya atau yang mengusahakan, serta bukan

38 Lihat Pasal 23 ayat (2) Peraturan Mahkamah Agung Republik Indonesia Nomor 2 Tahun 2008 tentang Kompilasi Hukum Ekonomi Syariah.

39 Lihat Salim Bahreisy dan Abdullah Bahreisy. Tarjamah Bulughul Maram Min Adillatil Ahkam. (Surabaya: Balai Buku, 1992), hlm. 385.

40 Lihat Departemen Agama RI, Al-Qur'an dan Terjemahannya, (Jakarta Timur: Darus Sunnah, 2002), hlm. 285. 
barang sengketa; Kelima, barang yang dijual atau dibeli diketahui oleh si penjual dan si pembeli, apakah barang dalam keadaan cacat atau tidak. ${ }^{41}$ Berkenaan dengan obyek di dalam akad muzara'ah dengan sistem murabahah yaitu berupa modal pertanian (meliputi benih, pupuk, alat pertania, dll) untuk transaksi pertama, dan kedelai untuk transaksi yang kedua dan ketiga.

3. Harga dan Keuntungan

Pada dasarnya, di dalam akad muzara 'ah sendiri tidak terkandung unsur harga mengingat akad ini merupakan akad kerjasama bentuk syirkah dengan unsur modal usaha di dalamnya. Hal ini berbeda dengan akad muzara'ah dengan sistem murabahah, dimana di dalam akad tersebut mengandung transaksi jual beli (murabahah), sehingga terdapat unsur harga di dalamnya yang menjadi unsur terpenting dalam setiap transaksi jual beli. Berkaitan dengan hal tersebut, ulama fiqh memberikan syarat atas harga di dalam suatu transaksi, yakni: ${ }^{42}$

1) Harga yang disepakati kedua belah pihak harus jelas jumlahnya.

2) Dapat diserahkan pada waktu akad (transaksi), sekalipun secara hukum seperti pembayaran dengan cek atau kartu kredit. Apabila barang itu dibayar kemudian (berhutang), maka waktu pembayarannyapun harus jelas waktunya.

3) Apabila jual beli dilakukan secara barter, maka barang yang dijadikan nilai tukar, bukan barang yang diharamkan oleh syara' seperti babi dan khamar, karena kedua jenis benda itu tidak bernilai dalam pandangan syara'.

Pada perjanjian akad muzara'ah dengan sistem murabahah ini, harga yang diberikan baik pada transaksi yang kedua dan yang ketiga berupa harga jual plus margin (keuntungan) yaitu harga pokok ditambah dengan keuntungan yang disepakati antara penjual dan pembeli. Terkait dengan pembayarannya, baik transaksi jual beli pertama antara Bank Syariah dengan petani kedelai, dan transaksi ketiga antara pedagang tempe (produsen tempe) dengan Bank Syariah, dapat dilakukan secara tunai maupun angsuran sesuai dengan kesepakatan para pihak. Berbeda halnya dengan pembayaran pada transaksi ketiga antara Bank Syariah dengan petani kedelai (yang pembeliaannya dikuasakan kepada pedagang tempe), maka pembayarannya dilakukan secara tunai, mengingat petani kedelai dalam hal ini berperan sebagai supplier (penjual) yang tidak terlibat langsung di dalam pembiayaan murabahah antara Bank

41 Lukman Haki, Prinsip-Prinsip Ekonomi Islam, (Jakarta: Penerbit Erlangga, 2012), hlm. 111-112. Lihat juga Pasal 24 Peraturan Mahkamah Agung Republik Indonesia Nomor 2 Tahun 2008 tentang Kompilasi Hukum Ekonomi Syariah.

42 M. Ali Hasan, Berbagai Macam Transaksi dalam Islam (Fiqh Muamalat), (Jakarta: RajaGrafindo Persada, 2003), hlm. 124-125. Lihat juga Aulil Amri, Denda dalam Bai' Bitsaman Ajil Menurut Fiqih Dan Fatwa Dewan Syariah Nasional (DSN), Jurnal JESKaPe, Vol. 2 No. 1 (Januari-Juni 2019), hlm. 65. 
Syariah dengan pedagang tempe (produsen tempe).

Sehubungan dengan keuntungan dalam akadini, semuapihakmemperolehkeuntungan, seperti pihak bank yang memperoleh 2 (dua keuntungan), yakni 1) keuntungan dari transaksi pertama berupa margin atas penjualan benih, pupuk, dan lain-lain; dan 2) keuntungan dari transaksi yang ketiga berupa margin pula atas penjualan kedelai kepada pedagang tempe. Lanjut pihak petani kedelai juga memperoleh 2 (dua) keuntungan, yakni: 1) keuntungan dari kerjasama muzara'ah berupa bagi hasil usaha, dan 2) keuntungan dari transaksi ketiga atas penjualan kedelai kepada bank. Adapula pula pihak penggarap yang mendapatkan keuntungan dari kerjasama muzara'ah berupa pembagian hasil usaha. Berkenaan dengan pedagang tempe (produsen tempe) dalam akad ini, meskipun tidak memperoleh keuntungan berupa margin, akan tetapi pedagang tempe memperoleh manfaat, sebab dapat membeli kedelai dengan harga murah, serta mendapatkan pembiayaan pula dari bank syariah yang tentunya hal tersebut dapat meningkatan hasil produksi usaha tempenya tersebut.

Berdasarkan penjelasan sebagaimana yang diuraikan di atas, maka dapat ditemukan keunggulandariakadmuzara'ah dengansistem murabahah ini, dimana petani kedelai dapat bekerjasama dengan Bank Syariah dalam hal pendanaan yang tentunya sangat dibutuhkan petani untuk meningkatkan kuantitas produksi dan kualitas kedelainya agar dapat memenuhi kebutuhan kedelai masyarakat, terutama sebagai bahan dasar tempe. Berkenaan dengan demikian, apabila kebututuhan kedelai masyarakat terpenuhi, maka pemerintah tidak perlu mengimpor kedelai dari negara lain, sehingga harga kedelai dalam negeri bisa terus stabil bahkan di tengah pandemi Covid-19. Hal ini dikarenakan pedagang atau produsen tempe dapat membeli langsung hasil panen kedelai kepada petani kedelai dengan harga yang terjangkau, bahkan jika produsen tempe tidak memiliki cukup biaya untuk membeli kedelai, produsen kedelai dapat mengajukan pembiayaan murabahah kepada bank syariah. Berkenaan dengan demikian pula, ketika pemerintah tidak lagi mengimpor kedelai, dan memanfaatkan kedelai lokal sebagai bahan utama tempe, maka harga kedelai dapat dikontrol oleh pemerintah Indonesia sendiri, sebab perputaran transaksi jual beli kedelai termasuk harga kedelai berada dilingkup petani kedelai dan produsen tempe selaku konsumen, dan hal ini membuat harga kedelai menjadi stabil. Petani kedelai dalam hal ini memperoleh keuntungan dari hasil penjualan kedelai dengan harga yang sesuai standar, begitu pula dengan produsen tempe memperoleh kedelai dengan harga yang terjangkau namun berkualitas, sehingga baik petani kedelai maupun produsen tempe tentu sangat diuntungkan. Hal ini menunjukkan bahwa akad muzara'ah dengan sistem murabahah merupakan akad yang efektif yang dapat digunakan di sektor pertanian kedelai guna menstabilkan harga kedelai di Indonesia. 


\section{Kesimpulan}

Berdasarkan pembahasan di atas, maka dapat disimpulkan bahwa karakteristik akad muzara'ah dengan sistem murabahah, meliputi 4 (empat) hal: Pertama, dari segi subyeknya di dalam akad muzara'ah dengan sistem murabahah ini terdiri dari 4 (empat) pihak yakni Bank Syariah, Petani Kedelai, Penggarap, dan Produsen Tempe, serta di dalamnya mengandung 3 (tiga) jenis akad yakni murabahah, muzara'ah, dan wakalah. Kedua, dari segi obyek, obyek di dalam akad muzara'ah dengan sistem murabahah yaitu berupamodalpertanian(meliputibenih,pupuk, alat pertania, dll) untuk transaksi pertama dan kedelai untuk transaksi yang kedua dan ketiga.
Ketiga, dari segi keuntungan, di dalam akad ini, pihak bank, petani kedelai, dan penggarap memperoleh keuntungan (margin), sedangkan pedagang tempe (produsen tempe) tidak memperoleh keuntungan berupa margin, akan tetapi produsen tempe memperoleh manfaat, sebab dapat membeli kedelai dengan harga murah. Keempat, petani kedelai yang tidak memiliki dana atau biaya atau modal untuk membeli benih, pupuk, alat-alat pertanian, dan lain sebagainya dapat mengajukan permohon pembiayaan kepada bank. Begitu pula dengan produsen tempe yang tidak memiliki dana untuk membeli kedelai sebagai bahan baku tempe, juga dapat mengajukan pembiayaan ke Bank Syariah.

\section{DAFTAR PUSTAKA}

\section{Buku}

Antonio, Muhammad Syafi'i. Bank Syariah Teori dan Praktek. Jakarta: Gema Insani, 2001.

Ascarya, Akad dan Produk Bank Syariah. Jakarta: RajaGrafindo Persada, 2008. As-Shiddieqy, Teungku Muhammad Hasbi. Hukum-Hukum Fikih Islam. Semarang: Pustaka Rizki Putra, 1997.

Burhanuddin. Hukum Kontrak Syariah. Yogyakarta: BPFE, 2009.

Departemen Agama RI. Al-Qur'an dan Terjemahannya. Jakarta Timur: Darus Sunnah, 2002.

Hakim, Lukman. Prinsip-Prinsip Ekonomi Islam. Jakarta: Penerbit Erlangga, 2012.
Hermanto, Bambang. Lembaga Keuangan Syari'ah. Pekanbaru : Suska Press, 2008.

M. Ali Hasan. Berbagai Macam Transaksi dalam Islam (Fiqh Muamalat). Jakarta: RajaGrafindo Persada, 2003.

Rivandi, Dhody Ananta dan Sholihah, Cucu. Akad Pembiayaan Murabahah di Bank Syariah dalam Bentuk Akta Otentik Imolementasi Rukun, Syarat, dan Prinsip Syariah. Malang: Cita Intrans Selaras, 2019.

Salim Bahreisy dan Abdullah Bahreisy. Tarjamah Bulughul Maram Min Adillatil Ahkam. Surabaya: Balai Buku, 1992. 
Soejono dan Abdurrahman. Metode Penelitian Hukum. Jakarta: Rineka Cipta, 2003.

Suhendi, Hendi. Fiqih Mu'amalah. Jakarta: Raja Grafindo Persada, 2013.

Susanti, Dyah Ochtorina dan Efendi, A'an. Penelitian Hukum (Legal Research). Jakarta: Sinar Grafika, 2014.

Susianto dan Rita. Fakta Ajaib Khasiat Tempe. Jakarta: Penebar Plus, 2013.

Tim Penyusun Direktorat Badan Peradilan Agama. Kompilasi Hukum Ekonomi Syariah. Jakarta: Direktorat Badan Peradilan Agama, Mahkamah Agung RI, 2011.

\section{Jurnal}

Agung, I Gusti Ayu Ari et. al. "Kedelai Lokal Bali, Bahan Baku Tempe Tinggi Nutrisi, Antioksidan Dan Organoleptik Serta Berkhasiat Obat". AGRIMETA: Jurnal Pertanian Berbasis Keseimbangan Ekosistem, Vol. 6 No. 12, (2016) : 87.

Amri, Aulil, Denda dalam Bai' Bitsaman Ajil Menurut Fiqih Dan Fatwa Dewan Syariah Nasional (DSN), Jurnal JESKaPe, Vol. 2 No. 1 (Januari-Juni 2019) : 65.

Nazaruddin. "Mukhabarah Sebagai Problem Solver Umat". Al-Mabhats: Jurnal Penelitian Sosial Agama Vol. 4, No. 2, (2019) : 103

Ngasifudin, Muhammad. "Aplikasi Muzara'ah Dalam Perbankan Syariah", Jurnal Ekonomi Syariah Indonesia Vol. VI, No. 1, (Juni 2016) : 40.
Nugraha, Jefri Putri. "Sistem Muzara'ah Sebagai Alternatif Pembiayaan Pertanian di Indonesia. Jurnal Iqtishodia Vol. 1, No. 2, (September 2016) : 87.

Prabowo, Bagya Agung, "Konsep Akad Murabahah Pada Perbankan Syariah (Analisa Kritis Terhadap Aplikasi Konsep Akad Murabahah di Indonesia dan Malaysia)", Jurnal Hukum Vol. 16 No. 1, (Januari 2009) : 108.

Primada, Beny Septyliyan, "Tinjauan Mekanisme Kontrak Pengelolaan Lahan Pertanian Berbasis Adat Istiadat Dalam Kajian Fiqh Muamalah (Desa Temu, Kecamatan Kanor, Kabupaten Bojonegoro)", JESTT Vol. 2, No. 11 (November 2015) : 959

Setiady, Tri "Pembiayaan Murabahah dalam Perspektif Fiqh Isam, Hukum Positif dan Hukum Syariah", Fiat Justisia Jurnal Ilm Hukum, Vol. 8 No. 3, (JuliSeptember 2014) : 521.

Wahyu,A.Rio Makkulau “Sistem Penggarapan Lahan Pertanian Masyarakat: Perspektif Ekonomi Islam", Al-Azhar Journal of Islamic Economics Vol. 1 No. 1, (Januari 2019) : 5.

Wahyuningrum, Ana Liana dan Darwanto, "Penerapan Bagi Hasil Maro Perspektif Akad Mukhabarah, Tawazun: Journal of Sharia Economic Law, Vol. 3 No. 1, (2020) : 49

Waryanto, Budi et.al (Ed). "Dampak Covid-19 Terhadap Sektor Pertanian”. 
Buletin Perencanaan Pembangunan

dan Pertanian, Volume 1 No.2, (April 2020) : 1 .

Tesis

Dyah Ochtorina Susanti. Pelaksanaan Perjanjian Pembiayaan Murabahah Dengan Sistem Bai'u Salam Ditinjau Dari Sudut Pandang Hukum Islam (Studi pada PT. BPRS Daya Artha Mentari Bangil - Pasuruan), Tesis. Malang: Program Pascasarjana Fakultas Hukum Universitas Brawijaya, 2006.

\section{Peraturan Perundang-Undangan}

Undang-Undang RI No. 21 Tahun 2008 tentang Perbankan Syariah.

Peraturan Mahkamah Agung Republik Indonesia Nomor 2 Tahun 2008 tentang Kompilasi Hukum Ekonomi Syariah.

\section{Internet}

https://www.bps.go.id/.

h t t p s : / / mon e y. k o m pas . c o m / $\mathrm{read} / 2020 / 08 / 23 / 071100726 /$ ironiindonesia-negeri-tempe-kedelainyamayoritas-impor?page $=$ all.

https://www.cnbcindonesia.com/ news/20210104144905-4-213360/ tahu-tempe-langka-terus-yang-salahpetani-kedelai-gitu.

https://finance.detik.com/berita-ekonomibisnis/d-5324643/harga-kedelai-rp$8500 \mathrm{~kg}$-ditahan-3-bulan.

https://www.antaranews.com/berita/2002109/ naik-lagi-harga-kedelai-impor-dikudus-rp9800-per-kilogram.

https://bisnis.tempo.co/read/312935/ pengusaha-tahu-tempe-di-jember-jugamulai-kelimpungan/full\&view=ok. 